Серія: Педагогічні науки. - Вип.3. - Бердянськ : БДПУ, 2019. - 453 с.

УДК 373.1:53:001.89:681.5

DOI 10.31494/2412-9208-2019-1-3-90-96

\title{
THE INFLUENCE OF EDUCATIONAL ROBOTECHNICAL CONSTRUCTORS ON THE DEVELOPMENT OF STUDENTS' COGNITIVE ACTIVITY
}

\author{
ВПЛИВ НАВЧАЛЬНИХ РОБОТОТЕХНІЧНИХ \\ КОНСТРУКТОРІВ НА РОЗВИТОК ПІЗНАВАЛЬНОЇ \\ АКТИВНОСТІ УЧНIВ
}

\author{
Volodymyr BONDARUK, \\ Postgraduate Student \\ Володимир БОНДАРУК, \\ https://orcid.org/0000-0002-0292-0957 \\ vova5007625@ukr.net \\ Lesya Ukrainka Eastern European Східноєвропейський національний \\ National University \\ $\triangle 9$ Potapova St., \\ Lutsk, Volyn region, 43021 \\ університет імені Лесі Українки \\ $\triangle$ вул. Потапова, 9 \\ Original manuscript received: October 22, 2019 \\ Revised manuscript accepted: December 11, 2019
}

\begin{abstract}
Over the past few years, growing toys are becoming increasingly popular. A special place among them began to occupy the children's training sets of designers, and in connection with the development of electronic computing equipment began to appear sets of training designers robotics. These designers are intended to develop not only the design abilities of children, but also the basics of algorithmic thinking, because they provide the possibility of programming children created structures. This, in turn, makes it possible to use them in school lessons in physics, mathematics and computer science. To date, the largest amount of methodical materials provided by the designers of the company LEGO. Formulating the problem. Therefore, it is worth noting the importance of developing methods for using educational designers in school lessons. In scientific publications, you can find many materials that address the importance of the development of small motility in children and its impact on mental development. However, there are almost no studies concerning the influence of educational constructors on the development of fine motor skills, mathematical thinking and design abilities. Materials and methods.

The study of the influence of educational constructors on cognitive activity of students is based on empirical methods: collection of scientific facts - analysis of scientific and methodological literature, textbooks and teaching aids; studying the results of pedagogical research. Results. According to the results of the analysis of scientific publications and methodical materials, the use of educational designers in preschool and elementary school helps to increase interest in education in general, and in the primary school increases interest in the study of physics, computer science and mathematics. Conclusions. Today, the study of the influence of educational designers on the formation of physical and technical knowledge of students is most developed in the methodological materials supplied with sets LEGO. However, these methods are not well suited for the introduction into the educational program of physics, mathematics and computer science in Ukrainian schools. Within the framework of the joint project,
\end{abstract}


the LEGO Foundation and the Ministries of Education are beginning to develop new methods for the implementation of educational designers in the educational process, but they are limited to elementary and pre-school education.

Key words: educational robotics, educational constructors, LEGO Education, cognitive activity, educational experiment.

Людину від тварин відрізняє не прямоходіння і не розвинений мозок, перш за все нас, відрізняє два нюанси в будові рук. По-перше, тільки в людини кисть складається в кулак. Начебто дрібниця, але саме кулак забезпечив нашому виду перевагу над іншими в процесі еволюції стискаючи кулак, людина збільшує жорсткість фралангових суглобів у чотири рази, при цьому зменшує площу удару, збільшуючи його силу в три рази, але головне - маленький, але важкий кулак з гострими кісточками $€$ ідеальною зброєю. 3 цієї причини сучасні боксери носять рукавички, а у всіх знайдених скелетів давніх людей кісточки збиті від постійної "роботи".

У 2012 році Девід Каррієр і Майкл Морган з університету в штаті Юта опублікували результати дослідження, яке стосувалося ролі людських рук у процесі еволюції. Виявилось, що розвиток людської руки позначений не лише необхідністю володіти різними інструментами, а, в першу чергу, потребою використовувати кулаки в боях за виживання. Результати дослідження опубліковані в Journal of Experimental Biology [1]. У порівнянні з мавпами люди мають коротші долоні й пальці, крім великих, які, натомість, довші, сильніші і гнучкіші. Але кулак це зовсім не тупа і груба сила, навіть якщо бойова функція була первинною. Навпаки зібрати тендітну і тонку кисть у сталевий кулак - найвище досягнення природної інженерії. Для рук потрібна точність і акуратність рухів, недоступна жодному іншому виду на Землі. Філософр І. Кант стверджував, що "рука - це мозок людини, що вийшов назовні". Саме кулак дав нам настільки універсальні руки, придатні для виробництва знарядь.

У 1909 році німецьким невропатологом Корбініаном Бродманом було опубліковано дослідження кіркової цитоархитектоніки під назвою "Vergleichende Lokalisationslehre der Großhirnrinde in ihren Prinzipien dargestellt auf Grund des Zellenbaues" (нім. порівняльні дослідження локалізації в корі головного мозку, іï фундаментальні основи представлені з огляду на їхню клітинну архітектуру). Бродман розробив карту функціональних областей кори головного мозку в людини (які зараз прийнято називати полями Бродмана), мавп та інших видів ссавців [2]. Згодом Костянтином фон Економо (нім. Constantin von Economo) i Георгом Н. Коскінасом (нім. Georg N. Koskinas) в 1925 році була опублікована більш детальна карта кори мозку [3].

Канадський нейрохірург Вайлдер Грейвс Пенфілд [4] займався лікуванням епілепсії. Під час операцій ним було проведено ряд дослідів, у результаті яких вдалося отримати детальну карту кори головного мозку. Пенфілд зміг уперше визначити ділянки мозку, що відповідають за мовлення. Також були досліджені моторна та сенсорна ділянки кори головного мозку. Експерименти проводились за допомогою електростимуляції ділянок кори мозку, активація яких спричиняла реакцію 
м'язів і різних органів. Відповідно до розмірів ділянки кори, що відповідає за певний орган, було створено скульптуру людини (ії називають терміном “Гомункулус Пенфрілда”), пропорції частин тіла якої зображують пропорції певних областей кори в головному мозку. Пальці рук, губи та язик у цій скульптурі значно більші, ніж ноги та тулуб, адже на них значно більше нервових закінчень і їхня активність активізує пропорційно більшу частину кори головного мозку [5].

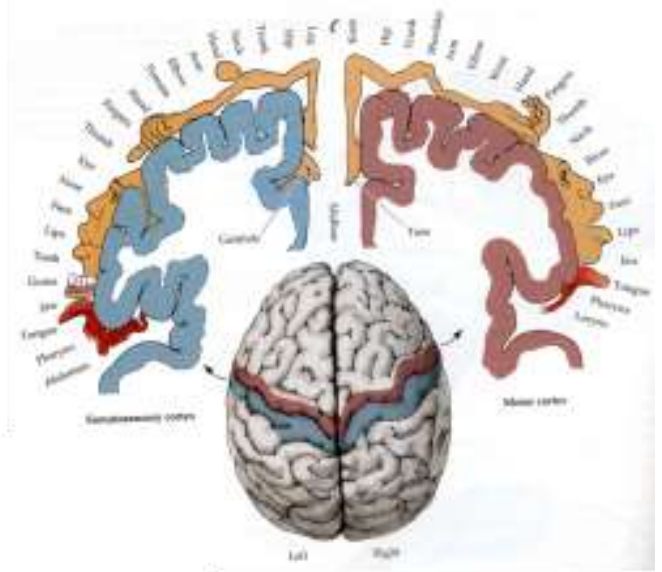

Звідси випливає, що руки і мозок перебувають у дуже тісному зв'язку. Наприклад, якщо втомилися руки - втомиться і вся ЦНС, і навпаки втомився мозок і кажуть, що "руки не піднімаються". Саме на цьому феномені побудована ідея конструктора, який послідовно проводить дітей через три етапи логічного мислення. Перший етап розвитку мислення характерний виключно дієвим методам пізнання зовнішнього світу і притаманний для дітей раннього віку. Таке мислення можна назвати "ручним", маніпулюючи предметами, дитина пізнає їх властивості. Це означає, що дитина раннього віку всі розумові завдання вирішує руками. Чим більше запас дій і проб накопичить у своєму досвіді дитина, тим швидше вона перейде до другого етапу - наочно-образного, коли буде оперувати не предметами, а їх образами. На цьому етапі дитина вирішує завдання, наприклад, з правильного розміщення фігур у відповідних отворах відразу, тому що проби виконуються в розумі. Третій етап - словесно-логічне або абстрактне мислення. Тут навіть практичні завдання вирішуються не руками, а в розумі. Таким чином, початок розвитку мислення дає рука. Як говорив фізіолог І. Павлов, "руки вчать голову, потім голова, яка порозумнішала, вчить руки, а вмілі руки знову сприяють розвитку мозку”.

Тобто конструктор дає дитині ноу-хау абстрактного мислення. Саме через дрібну моторику рук мозок сучасної людини отримує базові навички мислення. У цьому і фрішка конструктора - він складається з простих універсальних деталей, які вже своїм виглядом провокують абстрактне мислення. Гра з використанням конструктора вчить дітей молодшого віку 
розрізняти, оцінювати і комбінувати деталі різного кольору, розміру і форми. Крім цього, це може бути стимулом до розвитку мовленнєвих, інтелектуальних, пізнавальних і комунікативних здібностей. Через гру діти вчаться порівнювати предмети між собою і поділяти на частини, бачити спільне та відмінне, виділяти основні конструктивні елементи, від яких залежить розташування інших, робити висновки. Участь у конструкторській діяльності розвиває просторове мислення і навчає основних властивостей геометричних тіл, словниковий запас внаслідок цього поповнюється новими поняттями. Така діяльність також формує працьовитість, креативність мислення, самостійність, організованість.

У 2010 році започатковано проєкт “Сприяння освіті", основою для якого було підписання Меморандуму про взаєморозуміння між Міністерством освіти і науки України та фондом the LEGO Foundation (королівство Данія). Україна стала п'ятою державою у світі, яка приєдналася до програми. У 2014 році Інститутом інноваційних технологій та змісту освіти було проведено моніторингове дослідження ефективності впровадження проєкту, яке показало позитивний вплив гри 3 LEGO на розвиток мовлення, мислення, вміння працювати в команді та комунікувати між собою. Згідно з програмою перші класи всіх українських шкіл, які навчаються з 1 вересня 2018 року, мали отримати безкоштовні набори LEGO. Фонд LEGO має забезпечити наборами близько 17 тисяч шкіл з усієї України протягом 2018-2019 року [6] [7].

Крім власне наборів LEGO, фонд забезпечує достатню кількість методичних матеріалів. Так, у 2010 році схвалено до використання Програма розвитку конструктивних здібностей дітей дошкільного віку "ЛЕГО-конструювання" (автор Пеккер Т.В.), у 2016 році було випущено Програму розвитку дитини від 2 до 6 років та методичні рекомендації “Безмежний світ гри з LEGO" (керівник проєкту Рома О.Ю.) [8][9].

Програма розвитку конструктивних здібностей дітей дошкільного віку “ЛЕГО-конструювання" спрямована на роботу з дітьми 3-6 років 3 використанням засобів конструктора LEGO педагогами для гурткової роботи. Програма містить три освітні курси, оскільки розрахована на три роки навчання, кожен з яких спрямовано на роботу з дітьми певного віку: “Дослідники світу” - 3-4 роки; “Мандрівники на легольоті” - 4-5 років; “Юні техніки" - 5-6 років. Кожен з освітніх курсів побудований за таким змістом: Особливості вікового періоду; Завдання курсу; Зміст освітньої роботи та обладнання; Очікувані результати (рівень компетентності дитини).

Програма розвитку дітей від 2 до 6 років та методичні рекомендації «Безмежний світ гри з LEGO» створена за сприяння фонду ЛЕГО під керівництвом Рома О.Ю. з метою реалізації основних завдань дошкільної освіти. У методичних рекомендаціях пропонуються шляхи реалізації принципу "навчання через дію" за допомогою ЛЕГО конструктора. Програма поділена таким чином, щоб ії можна було використовувати разом з іншими програмами як педагогами, так і батьками. Програма має свою структуру, розділи укладені за віковими принципами, мають свої назви: ранній вік - "Знайомимося і робимо перші відкриття", молодший 
дошкільний вік - “Досліджуємо та відтворюємо”, середній дошкільний вік - “Пізнаємо та експериментуємо”, старший дошкільний вік - "Впевнено майструємо та імпровізуємо”. У методичних рекомендаціях подано тематику занять, варіанти ігор, сплановано зразок проєктної діяльності, спільну роботу з батьками, подано пропозиції щодо використання LEGO конструктора в роботі спеціалістів.

Згідно з програмами, методичними рекомендаціями з ЛЕГОконструювання основними завданнями $€$ зацікавити дітей у вивченні математики, сприяти пошуковій діяльності, поясненню своїх рішень, розвитку навичок логічного мислення. Однак не кожна програма, досвід, методичні рекомендації спрямовані на комплексне використання ЛЕГО конструктора. Для того, щоб дійсно розвивати математичні здібності, використовуючи ЛЕГО конструктор, педагог повинен творчо підходити до підбору матеріалу.

За даними психологів, мислення в дитини виникає в наочно-дієвій формі. Дитина спочатку мислить, сприймаючи предмети і практично діючи з ними. Через ці дії вона розкриває нові для неї властивості об'єктів. Зароджується наочно-дієве мислення в дитини в плані першої сигнальної системи. Далі воно опосередковується мовою дорослих і засвоюваним від них власним мовленням дитини, його функціонування і розвиток характеризується формуванням взаємозв'язків двох сигнальних систем, певних співвідношень образу, практичної дії і слова.

Здобуті в дослідженнях дані вказують на важливу роль практичних дій у мисленні дитини раннього віку, аналізі і синтезі об'єктів. Думки їі безпосередньо вплітаються в її дії, оскільки дитина думає тільки про те, що вона робить, і не може планувати своїх дій наперед, обдумувати, передбачати їх. У діях дитини зароджується і розуміння нею певних відношень предметів. У діях формуються тимчасові зв'язки, асоціації, нагромадження яких створює внутрішні умови виникнення і розвитку мислення дитини.

У дослідах Г. Костюка показана роль практичних дій у першому усвідомленні дітьми кількісних відношень речей. Це усвідомлення зароджується в процесі практичного оперування дітьми деякими множинами предметів (їх складання, розкладання тощо), зумовленого спілкуванням з дорослими. Потреба в ньому виникає при ускладненні умов дії, при розходженні зовнішнього вигляду і кількісного складу порівнюваних і відтворюваних дитиною множин предметів. Успіх дії в таких умовах стає можливим тільки там, де дитина може до усвідомити кількісну однаковість множин предметів при їх різному зовнішньому вигляді, зокрема різному просторовому розміщенні, абстрагувати кількість речей від інших їх ознак. Дитина раннього віку доходить до цього усвідомлення шляхом практичних дій, за допомогою яких вона розкладає задану множину на окремі елементи і по-новому їх об'єднує. Зіставляючи один по одному елементи утворюваної сукупності предметів з кожним їі елементом, вона доходить до вираженого в словах судження про їх кількісну однаковість. Усвідомлення її виникає в дитини раннього віку, як 
справжнє розв'язання нової задачі, яка здійснюється з допомогою раніше вироблених дій, шляхом актуалізації вже утворених тимчасових зв'язків, їх застосування у новій ситуації і нових асоціацій.

\section{Література}

1. Morgan, M. H. and Carrier, D. R. (2013). Protective buttressing of the human fist and the evolution of hominin hands.J. Exp. Biol. 216, 236-244.

2. Brodmann K (1909). Vergleichende Lokalisationslehre der Grosshirnrinde. Leipzig: Johann Ambrosius Barth.

3. Economo, C.; Koskinas, G.N. (1925). Die Cytoarchitektonik der Hirnrinde des erwachsenen Menschen (de). Wien \& Berlin: Springer.

4. Вайлдер Пенфілд [Електронний ресурс] / - Режим доступу: https://uk. wikipedia.org/wiki/\%D0\%92\%D0\%B0\%D0\%B9\%D0\%BB\%D0\%B4\%D0\%B5\% D1\%80 \%D0\%9F\%D0\%B5\%D0\%BD\%D1\%84\%D1\%96\%D0\%BB\%D0\%B4

5. Кортикальний гомункулус [Електронний ресурс] / - Режим доступу: https://uk. wikipedia.org/wiki/\%D0\%9A\%D0\%BE\%D1\%80\%D1\%82\%D0\%B8\%D0\%BA\% D0\%B0\%D0\%BB\%D1\%8C\%D0\%BD\%D0\%B8\%D0\%B9 \%D0\%B3\%D0\%BE\%D0\%BC \%D1\%83\%D0\%BD\%D0\%BA\%D1\%83\%D0\%BB\%D1\%83\%D1\%81

6. Проект LEGO «Сприяння освіті» в Україні [Електронний ресурс] / Режим доступу: https://mon.gov.ua/ua/osvita/doshkilna-osvita/profesijnaskarbnichka/proekt-lego-spriyannya-osviti-v-ukrayini

7. Усі перші класи в Україні безкоштовно отримають набори LEGO меморандум між MOH та THE LEGO FOUNDATION[Електронний ресурс] / - Режим доступу: $\quad$ https://mon.gov.ua/ua/news/usi-pershi-klasi-v-ukrayini-bezkoshtovnootrimayut-nabori-lego-memorandum-mizh-mon-ta-lego-foundation

8. Програма розвитку дитини від 2 до 6 років та методичні рекомендації «Безмежний світ гри з LEGO» / Рома О.Ю., Близнюк В.Ю., Борук О.П., - the LEGO ${ }^{\circledR}$ Foundation, 2016.-140c.

9. Програма розвитку конструктивних здібностей дітей дошкільного віку «ЛЕГО-конструювання», автор Пеккер Т.В., М. А., Голота Н. М., Терещенко О. П., Резніченко І. Ю.-Київ, 2010

\section{References}

1. Morgan, M. H. and Carrier, D. R. (2013). Protective buttressing of the human fist and the evolution of hominin hands.J. Exp. Biol. 216, 236-244.

2. Brodmann K (1909). Vergleichende Lokalisationslehre der Grosshirnrinde. Leipzig: Johann Ambrosius Barth.

3. Economo, C.; Koskinas, G.N. (1925). Die Cytoarchitektonik der Hirnrinde des erwachsenen Menschen (de). Wien \& Berlin: Springer.

4. Wilder Penfield[Wilder Penfield] . Retrieved from https://uk. wikipedia.org/ wiki/\%D0\%92\%D0\%B0\% D0\%B9\%D0\%BB\%D0\%B4\%D0\%B5\%D1\%80 \%D0\%9F\%D 0\%B5\%D0\%BD\%D1\%84\%D1\%96\%D0\%BB\%D0\%B4

5. Kortykalnyi homunkulus [Cortical homunculus]. Retrieved from https://uk. wikipedia.org/wiki/\%D0\%9A\%D0\%BE\%D1\%80\%D1\%82\%D0\%B8\%D0\%BA\% D0\%B0\%D0\%BB\%D1\%8C\%D0\%BD\%D0\%B8\%D0\%B9 \%D0\%B3\%D0\%BE\%D0\%BC \%D1\%83\%D0\%BD\%D0\%BA\%D1\%83\%D0\%BB\%D1\%83\%D1\%81

6. Proekt LEGO «Spryiannia osviti» v Ukraini [LEGO project "Promoting Education" in Ukraine]. Retrieved from https://mon.gov.ua/ua/osvita/doshkilnaosvita/profesijna-skarbnichka/proekt-lego-spriyannya-osviti-v-ukrayini

7. Usi pershi klasy $v$ Ukraini bezkoshtovno otrymaiut nabory LEGO Memorandum mizh MON ta The LEGO Foundation [All first classes in Ukraine will receive LEGO sets for free - Memorandum between MES and The LEGO Foundation]. 
Серія: Педагогічні науки. - Вип.3. - Бердянськ : БДПУ, 2019. - 453 с.

Retrieved from https://mon.gov.ua/ua/news/usi-pershi-klasi-v-ukrayini-bezkoshtovnootrimayut-nabori-lego-memorandum-mizh-mon-ta-lego-foundation

8. Roma O.U., Blyzniuk V.U., Boruk O.P. (2016) Prohrama rozvytku dytyny vid 2 do 6 rokiv ta metodychni rekomendatsii «Bezmezhnyi svit hry z LEGO» [ Child Development Program from 2 to 6 years old and guidelines for "The Endless World of LEGO Play"] the LEGO ${ }^{\circledR}$ Foundation[in Ukrainian].

9. Pekker T.V., Holota N. M., Tereshchenko O. P., Reznichenko I. U.( 2010) Prohrama rozvytku konstruktyvnykh zdibnostei ditei doshkilnoho viku «LEGOkonstruiuvannia»[ Program of development of constructive abilities of children of preschool age "LEGO-designing"] Kyiv[in Ukrainian]..

\section{АНОТАЦІЯ}

Протягом останніх років усе більшої популярності набувають розвивальні іграшки. Особливе місце серед них почали займати дитячі навчальні набори конструкторів, а у зв'язку з розвитком електронно-обчислюваної техніки з'явилися набори навчальних конструкторів робототехнічного спрямування. Вони призначені розвивати не лише конструкторські здібності в dimeй, a й сорормувати основи алгоритмічного мислення, оскільки передбачають можливість програмування створених дітьми конструкцій. Це, у свою чергу, дає можливість використовувати їх на шкільних уроках фрізики, математики та інформатики. На сьогоднішній день найбільшою кількістю методичних матеріалів забезпечені конструктори компанії ЛЕГО. Тому варто зауважити важливість розробки методик використання навчальних конструкторів на уроках. У наукових публікаціях можна знайти багато матеріалів, які стосуються важливості розвитку дрібної моторики в дітей і ї впливу на розумовий розвиток. Однак майже відсутні дослідження, що стосуються впливу навчальних конструкторів на розвиток дрібної моторики, математичного мислення і конструкторських здібностей. Дослідження впливу навчальних конструкторів на пізнавальну активність учнів грунтується на емпіричних методах: збір наукових фрактів - аналіз наукової та методичної літератури, підручників i навчальних посібників; вивчення результатів педагогічних досліджень. Зәідно з результатами аналізу наукових публікацій $i$ методичних матеріалів використання навчальних конструкторів у дошкільному віці і початковій школі допомагає підвищити інтерес до навчання загалом, а в основній школі підвищує інтерес до вивчення фрізики, інсрорматики $i$ математики. На сьогодні дослідження впливу навчальних конструкторів на формування фрізичних і технічних знань учнів найбільш розвинені в методичних матеріалах, що постачаються разом з наборами ЛЕГО. Однак ці методики мало пристосовані для впровадження в освітню програму з фрізики, математики та інфрорматики в українських школах. У рамках спільного проєкту the LEGO Foundation та Міністерства освіти і науки України починають розроблятись нові методики впровадження навчальних конструкторів в освітній процес, але вони поки обмежуються початковою і дошкільною освітою.

Ключові слова: освітня робототехніка, навчальний конструктор, LEGO Education, пізнавальна активність, навчальний експеримент. 